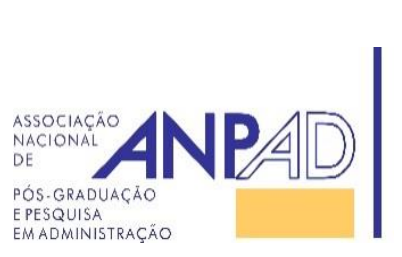

Available online at http://www.anpad.org.br/bar

BAR, Rio de Janeiro, v. 15, n. 2, art. 4, e180019, 2018

\title{
Microcredit and Gender: Are There Differences in the Credit Conditions?
}

Received 4 February 2018; received in revised form 30 April 2018; accepted 21 May 2018; first published online 22 June 2018.

Editor's note. Marcelo Cabus Klotzle served as Action editor for this article. 


\begin{abstract}
By means of a distinguished approach of credit granting, microcredit programs stand out as a socioeconomic alternative for social insertion and fighting against poverty. In this context, a factor that has gained prominence in literature is the female participation in these programs. Therefore, knowing that the literature indicates that there is a lower level of default among women, and considering that gender influence over the financing value has been disproportionate, the aim of this research was to evaluate the relationship between gender and the amounts which were granted in microcredit operations. In order to achieve this, a multiple linear regression technique was used on a sample of 4,454 microcredit clients of a bank with branches located in Paraíba, Brazil. Primary data collection was carried out together with the branch managers by consulting their system. Data were randomly chosen, and refer to the period from January to December 2016. Results show that women obtain a higher credit value than men, which is the opposite of what was found in literature.
\end{abstract}

Key words: gender; microcredit; credit conditions. 


\section{Introduction}

By means of a distinguished approach to granting credit, microcredit programs stand out as a socioeconomic alternative of social insertion and the fight against poverty (Arbolino, Carlucci, Cirà, Yigitcanlar, \& Ioppolo, 2018; Bezboruah \& Pillai, 2017; Dutta \& Banerjee, 2018), placing the credit granted as a propellant for formal and informal microenterprises (Alves \& Camargos, 2014). In general, microcredit provides financing to low income families to let them acquire essential assets and deal with certain unexpected expenses (Akotey \& Adjasi, 2016).

In this context, a factor that has gained prominence in discussions is female participation in microcredit programs. Around the world, the level of microcredit is estimated to be more than 12 billion US dollars, and its beneficiaries include nearly 200 million clients, of whom $3 / 4$ are women (Wahidi, 2017). In Brazil, in the third quarter of 2015, women represented $62.13 \%$ of the clients assisted by the National Program of Guided Productive Microcredit (Ministério do Trabalho e Previdência Social, 2015). It is noteworthy that microfinance practitioners and policymakers target women to help them earn income, gain financial independence and strengthen their decision-making power within the household and society (Zhang \& Posso, 2017).

In this regard, some studies that aimed to evaluate conditioners or factors that influence the accessibility of microcredit have used gender differences among their variables, but from different perspectives and with equally differentiated results. Mazumder, Dastidar and Bhandari (2017) analyzed the factors underlying credit accessibility of rural households among rural microentrepreneurs in India. They showed that gender of the entrepreneur has a dominant and significant impact on access to credit, indicating gender discrimination in access to credit where male respondents were more favored in accessing formal credit than females.

The study by Wahidi (2017) emphasized the characteristics of beneficiaries of microcredit allocated by MFIs (microfinance institutions) in Lebanon. The results seem to show that NGO MFIs give more credit to men than to women. In addition, the results of the interviews with MFI administrative officials seem to show that male loan officers may distinguish between male and female beneficiaries and prefer to grant microcredit to a man.

Bahta, Strydom and Donkor (2017) examined the extent to which gender influences access to microcredit for farmers in Eritrea, Africa. The empirical results showed that women are less likely to be able to access microcredit, compared to men. The men have a $34.8 \%$ probability of accessing microcredit while women are only likely to access microcredit at $17.9 \%$ (the mean difference of microcredit access is $16.9 \%$ ). The implication is that men have a $16.9 \%$ higher probability of accessing microcredit than women, suggesting that women have limited access to microcredit.

Other data can be found in Gosh and Vinod's (2017) study that analyze Indian data and suggest a significant disparity in both access and use of gender financing. The study reveals that, on average, female-headed families are $8 \%$ less likely to have access to formal financing. They are also $6 \%$ more likely to have access to informal financing that male-headed families.

On the other hand, studies conducted in the Brazilian context have demonstrated a positive scenario in relation to women and their participation in microcredit programs. Soares, Barreto and Azevedo (2011), for example, have investigated the importance of some factors that facilitate the way out of poverty for Crediamigo/BNB clients. They discovered that there are more women than men as active clients in this program, and women present a lower level of default. This last aspect is corroborated by Alves and Camargo (2014), who evaluated the default conditioning factors in microcredit operations granted by two microcredit institutions. They found out that men presented an increase of $7.3 \%$ in the default probability, indicating that women have a lower credit risk when compared to men. 
A factor that may be affected by women's lower default is the amount contracted with microcredit providers. Therefore, it is expected that the contracted value has a positive correlation with female gender, an aspect that was not yet explored in depth in Brazilian literature. However, in the study conducted by Agier and Szafarz (2013), whose aim was to test if both women and men would benefit from the same credit conditions in Brazilian microcredit institutions, the authors discovered that there is no gender bias related to loan denials, but there is differentiated treatment regarding credit conditions.

Thus, the authors noted that there is a glass ceiling effect - in reference to a barrier that is so subtle that it is transparent, but strong enough to make it impossible for women to ascend (Steil, 1997) - in which the amount of granted credit is disproportionate in relation to gender, with women being negatively affected. It is worth emphasizing that analyses regarding the glass ceiling were also developed from different perspectives, and the most common is related to work (in organizations), as in Steil's (1997) study.

It is also worth noting that there are several theoretical reasons that explain a possible gender difference in the access to financial services, such as: (a) there may be taste discrimination in the sense that the financial system is dominated by man and the barriers related to financial services are consequently higher for women than men; (b) there may be statistical discrimination in the sense that a lower education level and involvement in the formal market economy is a barrier that prevent women from having access to formal financial services; (c) a lower involvement in the formal market economy may also reflect a distribution of traditional roles in society, in which women focus on domestic activities and men focus on the market economy (Al-Shami, Majid, Mohamad, \& Rashid, 2017; Aterido, Beck, \& Iacovone, 2013; Corsi \& Angelis, 2017).

Therefore, since the literature indicates that there is a lower default among women and taking into account that the aspect of gender influence on the financing value is disproportionate, although little explored in studies, the aim of this research was to evaluate the relationship between gender and the amounts which were granted in microcredit operations. In order to do so, the article is structed as follows: first, there is a discussion about the theoretical aspects related to microcredit and, more specifically, regarding the female role in this scenario; then, there is a description of the methodology; finally, there is a brief discussion regarding the results obtained in the study and the conclusion.

\section{Theoretical Background}

\section{Microcredit: general discussions}

Small businesses, urban or rural, formal or informal, have suffered from a shortage of capital, resulting in low productivity and low incomes, which prevents the multiplier effect of income and the inclusive economic development in macroeconomic terms (Arbolino et al., 2018; Zouain \& Barone, 2007). In this sense, in most countries around the world, credit has shown to be an instrument that leverages development, placing it as a necessary condition for making resources flow in economies (Enimu, Eyo, \& Ajah, 2017).

In fact, one thing that has been perceived in literature is that credit support has been strongly pointed out as of the big challenges to boost the development of formal and informal microenterprises, contributing to income and employment generation for the development of backward regions (Alves \& Camargos, 2014; Carlucci, Cirà, Immordino, Ioppolo, \& Yigitcanlar, 2017; García-Pérez, MuñozTorres, \& Fernández-Izquierdo, 2017; Rakib, Chakrabarty, \& Winn, 2018). This happens because, without access to financial resources, individuals face difficulties in starting, maintaining and expanding their economic activities, sustaining poverty and income inequality (Bilau \& St-Pierre, 2018; Chliova, Brinckmann, \& Rosenbusch, 2015; Soares, Barreto, \& Azevedo, 2011). 
In Brazil, following the logic outlined above, microcredit is the most visible and developed part within a complex set of tools for generating income and combating poverty. This means low-value loans for small entrepreneurs, microenterprises and small-sized companies that have no access to the traditional financial system, mainly because they cannot offer real guaranties (Al-Shami et al., 2017; Serrano-Cinca, Gutiérrez-Nieto, \& Reyes, 2016).

Microcredit programs can therefore be considered one of the most popular development strategies (Enimu et al., 2017; Ghosh \& Neogi, 2017; Ugwuja \& Nweze, 2018; Wahidi, 2017), whose objective is to serve the poor, many of whom do not have access to traditional banking services, without the need for the borrower to present some kind of guarantee (Al-Shami et al., 2017; Armstrong, Ahsan, \& Sundaramurthy, 2018; Milanov, Justo, \& Bradley, 2015; Thanh \& Duong, 2017; Wahidi, 2017).

Given these characteristics, there seems to be a consensus that microcredit is an important contemporary mechanism for reducing poverty and social inequalities, which has led several developing countries to stimulate this modality of credit, even as a development policy (Arbolino et al., 2018; Bezboruah \& Pillai, 2017; Bidisha, Khan, Imran, Khondker, \& Suhrawardy, 2017; Dutta \& Banerjee, 2018; Li, Gan, \& Yu, 2011; Thanh \& Duong, 2017; Ugwuja \& Nweze, 2018).

In addition, studies also point out the influence that microcredit has on welfare, such as the case developed by Al-Shami, Majid, Mohamad and Rashid (2017), indicating that productive microcredit loans have a significant positive influence over family welfare.

In general, borrowers make investments to create, resume or develop an activity capable of generating income, but also to implement life projects such as the purchase of housing, job search, geographical mobility, follow-up training, etc. (Wahidi, 2017). This shows how microcredit plays a key role in the development of small entrepreneurial or family businesses, and is capable of improving the income condition of less-favored classes.

Some elements may be decisive for the success or failure of this kind of program, such as its format, regarding the volume and type of granted credit; payment deadlines for customers; borrowers' individual characteristics, such as educational level and age; or types of enterprises to be financed, such as their region of operation (Soares et al., 2011).

Finally, Leismann and Carmona (2010) warn that microcredit should not be seen as the only remedy to solve poverty, which is multidimensional. However, it is one of the mechanisms found to enable an increase of income in activities whose marginal incomes are high and where access to credit can improve the life conditions of individuals and their families. Thus, this kind of program has shown its relevance in specific situations, such as the loss of a job, exclusion from the labor market, destitution of land or inequality between genders (Santos \& Carrion, 2009).

\section{The role of women in microcredit}

Based on the discussions found in the previous session, we can see how microcredit is used as policy, aiming at economic development and the fight against poverty. The fact is that in recent years a great emphasis has been put on microfinance, hoping that poverty might be reduced and women's empowerment might be promoted. Thus, microfinance programs have focused on millions of women living in developing countries, helping them to have access to microcredit services (Bezboruah \& Pillai, 2017; Haile, Bock, \& Folmer, 2012; Wahidi, 2017; Zhang \& Posso, 2017).

In this way, the special attention that women receive from these programs is added to the discussion, especially when it is considered that the lack of access to finance prevents both female entrepreneurship and their participation in the modern market economy (Aterido et al., 2013; Guérin, D'Espallier, \& Venkatasubramanian, 2015; Mazumder, Dastidar, \& Bhandari, 2017). In this sense, the concept of empowerment is highlighted in the logic of microcredit provisions for women, since this reflects women's capacity to undertake new economic activities (Al-Shami et al., 2017; Bahta, Strydom, \& Donkor, 2017; Bezboruah \& Pillai, 2017; Tahir, Kauser, Bury, \& Bhatti, 2018; Zhang \& Posso, 2017). 
Empowerment can be understood as a changing process through which individuals increase their ability to exercise their choice and freedom, which contributes positively to their well-being (Ganle, Afriyie, \& Segbefia, 2015). In other words, empowerment means having broadened choices in life, gaining more control over it, and generally reaching the capacity to live it as one wishes to live (Mahmud, Shah, \& Becker, 2012; Tahir et al., 2018).

Thus, in the vast majority of cases, microcredit programs have given special attention to female clients, giving them greater control over resources, ownership and business operations, as well as skills to contribute to income for their families, which helps them to become stronger and more respected (AlShami et al., 2017; Chliova et al., 2015; Dutta \& Banerjee, 2018; Garikipati, Johnson, Guérin, \& Szafarz, 2017).

One of the justifications to the attention that is given to women regarding microcredit refers to the high reimbursement rate presented by them. In general, women present good credit risks and there is no lack of studies that claim that women outnumber men in terms of reimbursement - see, for example, Brana (2013), Bezboruah and Pillai (2017), Bahta et al. (2017), Al-Shami et al. (2017) and Bilau and St-Pierre (2018). Ghosh and Neogi (2017) argued that lending to women is safer due to the fact that they are less likely to default, less likely to misuse the loan, and more likely to share the benefits with other family members in their household, especially with their children.

By analyzing this particular aspect, Alves and Camargos (2014) indicate that non-repayment, which means default, can be considered as the main problem of the microfinance sector, since it can increase transaction costs and harm financial sustainability and organization growth. Therefore, the fact that women have lower credit risks when compared to men may be an attractive feature for microcredit agencies.

Also in this context, Bahta et al. (2017) and Das (2017) argue that, in general, women have fewer credit opportunities when compared to men, which causes them to seek to repay their loans in order to guarantee continued access to credit. Agencies see in women contracts that are easier to control and enforce, making them useful to these agencies (D’Espallier, Guérin, \& Mersland, 2011). This makes it clear that the idea of having this target audience, besides being seen as the right thing to do, is also a strategic action, designed to facilitate easier credit recovery (Ganle et al., 2015).

However, despite the prominent role that women play in microcredit scenario, in terms of the amount granted to them, the results show a reality in which there are certain differences in relation to men. For example, in the study conducted by D'Espallier, Guérin and Mersland (2011) with a set of 350 microcredit institutions in 70 countries, which aimed to analyze the common belief that women generally present better credit risks that men, it was discovered that female clients are associated with lower loan values.

In the same sense, the research developed by Ganle, Afriyie and Segbefia (2015), with rural women that are involved in a microcredit program in Ghana, revealed that most (92\%) women that were served by the program believed that the amount granted was not enough. According to the authors, in this specific case, women stated that the reduced size of loans did not allowed them to make good investments that could generate high incomes, making them stop investing their loans in compensatory activities and values, and making it difficult to repay the values, making women more vulnerable and powerless.

The study by Ugwuja and Nweze (2018) was carried out to investigate micro-loan sizes accessed by male and female small-scale agro-entrepreneurs in the Niger Delta region of Nigeria on a comparative basis. Available statistics confirmed that there was a significant difference between the mean amount of loan, accessed by male and female in relation to the semiformal loans.

On the other hand, the study by Agier and Szafarz (2013), which aimed to analyze whether men and women benefit from the same credit conditions, using 34,000 loan applications from a Brazilian microcredit institution, discovered that there was no gender bias related to loan denial, whereas there was different treatment related to credit conditions. 
Similarly, Corsi and Angelis (2017) followed the same methodology used by Agier and Szafarz (2013) on data from a microfinance programme in Uganda, but their results showed no sign of a significant gender gap in loan size.

What can be inferred from this discussion is that, for women, who often lack the necessity guarantees or preconditions to obtain credit through formal institutions, microcredit is very important (Nader, 2008). These programs increasingly focus on this audience for many reasons, such as: (a) the cost-effectiveness rationale, since women's reimbursement rates have been much higher than those presented by men; (b) capital ratio, considering that women have less access to productive employment in countries' development; and (c) because women invest a large part of the borrowed amounts in their children and families, generating a multiplier effect that improves the effectiveness of credit funds (Ghosh \& Neogi, 2017; Nader, 2008).

Therefore, although gender is a well debated subject in the academic world regarding, for example, inequalities between men and women at work (Abendroth, Melzer, Kalev, \& TomaskovicDevey, 2017), it seems clear that gender is a fundamental field in microcredit programs, and still allows some explorations of its characters and behavior in different realities.

\section{Methodological Procedures}

The main objective of this study is to evaluate the relationship between the gender and the amounts which were granted in microcredit operations. In order to do so, a multiple linear regression was used as a data analysis method. The use of a multiple linear regression allows explicit control in many aspects that simultaneously affect the dependent variable. Thus, this method can be used to build better models to predict the dependent variable (Wooldridge, 2012).

The sample is made up of 4,454 microcredit clients of branches of a bank that is located in Paraíba, Brazil, which was chosen due to its representativeness in the state and due to accessibility to data. The microcredit program of this institution is the largest in South America, performing 15,500 operations per day on average and having a portfolio of 1.9 million active clients. The data collection was carried out primarily with the managers of the respective of agencies, by consulting their system. The data were randomly chosen, and refer to the period from January to December 2016. The proposed model is presented in Equation 1.

$$
\begin{aligned}
& \text { lContractedamount }=\beta_{0}+\beta_{1} * \text { Gender }+\beta_{2} * \text { Age }+\beta_{3} * \text { CivilStatus }+ \\
& \beta_{4} * \text { RiskRating }+\beta_{5} * \text { Income }+\beta_{6} * \text { TypeofInvestment }+\beta_{7} * \text { Residence }+ \\
& \beta_{8} * \text { Default }+u
\end{aligned}
$$

Where 1Contractedamount represents the log of the amount granted to the clients (in BRL); Gender is a binary variable of the client's gender, in which 1 is female and 0, if otherwise; Age represents the client's age (in years); Civil Status is a binary variable of the client's civil status, in which 1 is married and 0, if otherwise; Risk Rating refers to the risk level of the operation; Income represents the client's income (in BRL); Type of Investment is a binary variable of the type of investment that the client will perform with the loan, in which 1 is fixed and 0 , if otherwise; Residence is a binary variable of the client's place of residence, in which 1 is rural and 0 , if otherwise; Default is a binary variable of the client's situation, if the client is defaulting, and 0 if otherwise. The dependent variable (lContractedAmount) and the independent variables and descriptions, as well as the baseline references, are presented in Table 1. 
Table 1

\section{Variables Used}

\begin{tabular}{|c|c|c|}
\hline VARIABLES & AUTHORS & DESCRIPTION \\
\hline 1Contracted Amount ${ }^{a}$ & $\begin{array}{c}\text { Nader (2008); Soares et al. (2011); Malapit } \\
\text { (2012); Camargos, Camargos and Araujo } \\
\text { (2012); Agier and Szafarz (2013); Corsi and } \\
\text { Angelis (2017) }\end{array}$ & $\begin{array}{l}\text { Log of the amount granted to the } \\
\text { clients (in BRL) }\end{array}$ \\
\hline Gender & $\begin{array}{l}\text { Soares et al. (2011); D’Espallier et al. (2011); } \\
\text { Li, Gan and Yu (2011); Malapit (2012); Agier } \\
\text { and Szafarz (2013); Brana (2013); Alves and } \\
\text { Camargos (2014); Milanov, Justo and Bradley } \\
\text { (2015); Akotey and Adjasi (2016); Corsi and } \\
\text { Angelis (2017); Wahidi (2017); Bahta } \text { et al. } \\
\text { (2017); Rakib, Chakrabarty and Winn (2018) }\end{array}$ & $\begin{array}{l}\text { Binary variable of the client's } \\
\text { gender, in which } 1 \text { is female and } 0 \text {, } \\
\text { if otherwise }\end{array}$ \\
\hline Age & $\begin{array}{l}\text { Nader (2008); Soares et al. (2011); Li et al. } \\
\text { (2011); Mahmud, Shah and Becker (2012); } \\
\text { Malapit (2012); Agier and Szafarz (2013); } \\
\text { Milanov et al. (2015); Vyas, Jansen, Heise and } \\
\text { Mbwambo (2015); Corsi and Angelis (2017); } \\
\text { Akotey and Adjasi (2016); Ghosh and Vinod } \\
\text { (2017); Mazumder et al. (2017); Wahidi (2017); } \\
\text { Bahta } \text { et al. (2017); Rakib et al. (2018); Ugwuja } \\
\text { and Nweze (2018) }\end{array}$ & The client's age (in years) \\
\hline Civil Status & $\begin{array}{c}\text { Nader (2008); Agier and Szafarz (2013); Brana } \\
\text { (2013); Alves and Camargos (2014); Corsi and } \\
\text { Angelis (2017); Akotey and Adjasi (2016); } \\
\text { Wahidi (2017); Bahta et al. (2017); Ugwuja and } \\
\text { Nweze (2018) }\end{array}$ & $\begin{array}{l}\text { Binary variable of the client's civil } \\
\text { status, in which } 1 \text { is married and } 0 \text {, } \\
\text { if otherwise }\end{array}$ \\
\hline Risk Rating & $\begin{array}{c}\text { Brazilian Central Bank (Resolução n. 2.682, } \\
\text { 1999) }\end{array}$ & $\begin{array}{l}\text { Percentage of provision (levels of } \\
\text { risk: } \mathrm{AA}-0,0 \% ; \mathrm{A}-0,5 \% ; \mathrm{B}- \\
1,0 \% ; \mathrm{C}-3,0 \% ; \mathrm{D}-10,0 \% ; \mathrm{E}- \\
30,0 \% ; \mathrm{F}-50,0 \% ; \mathrm{G}-70,0 \% ; \mathrm{H}- \\
100 \%)\end{array}$ \\
\hline
\end{tabular}

Nader (2008); Li et al. (2011); Soares et al. (2011); Malapit (2012); Alves and Camargos (2014); Akotey and Adjasi (2016); Corsi and
Angelis (2017); Ghosh and Vinod (2017);

The client's income (in BRL)

Mazumder et al. (2017); Ugwuja and Nweze (2018)

\begin{tabular}{|c|c|c|}
\hline Type of Investment & $\begin{array}{l}\text { Alves and Camargos (2014); Agier and Szafarz } \\
\qquad(2013)\end{array}$ & $\begin{array}{l}\text { Binary variable of the type of } \\
\text { investment that the client will } \\
\text { perform with the loan, in which } 1 \\
\text { is fixed and } 0 \text {, if otherwise }\end{array}$ \\
\hline Residence & $\begin{array}{c}\text { Li et al. (2011); Akotey and Adjasi (2016); } \\
\text { Ghosh and Vinod (2017); Ugwuja and Nweze } \\
\text { (2018) }\end{array}$ & $\begin{array}{l}\text { Binary variable of the client's } \\
\text { place of residence, in which } 1 \text { is } \\
\text { rural and } 0 \text {, if otherwise }\end{array}$ \\
\hline Default & $\begin{array}{l}\text { Camargos, Camargos, Santos, Rodrigues and } \\
\text { Silva (2010); Soares et al. (2011); Camargos et } \\
\text { al. (2012); Alves and Camargos (2014) }\end{array}$ & $\begin{array}{l}\text { Binary variable of the client's } \\
\text { situation, if the client is defaulting, } \\
\text { and } 0 \text { if otherwise }\end{array}$ \\
\hline
\end{tabular}

Note. Source: Research data. aDependent variable. 
It is worth mentioning that the source for the risk criterion is based on the bank rules from which the data were collected, which take into account the standards established by the Brazilian Central Bank. In addition, it should be noted that all variables used in the model were chosen based on studies and were used by the authors indicated in Table 1 .

\section{Result Analysis}

Table 2 is presents the descriptive statistics of the data collected in the research. For the purpose of analysis, it can be seen from the table above that the variables that are not dummies (the ones that are not 1 or 0 ) present the following contexts: the variable log of the contracted amount shows that the minimum contracted amount was 6,131 and the maximum was 9,388; the age variable shows that there are clients in the sample with a minimum age of 19 years and a maximum age of 88 years; the risk classification variable presents the $\mathrm{H}$ level (100\%) and the level A (5\%) as the highest level of risk according to the provision table; and that the income variable shows that that are clients with the maximum income of $7400 \mathrm{BRL}$ and minimum of 0 . This fact justifies, as an example, the non-use of this variable in the log form, which at first would be more advisable for monetary values, but which does not admit null value, as Wooldridge (2012) points out.

Table 2

\section{Descriptive Statistics}

\begin{tabular}{cccccc}
\hline Variable & Obs & Mean & Std. Dev. & Min & Max \\
\hline IContractedamount & 4454 & 8.164 & 0.377 & 6.131 & 9.388 \\
Gender & 4454 & 0.482 & 0.516 & 0 & 1 \\
Age & 4454 & 46.160 & 15.050 & 19 & 88 \\
CivilStatus & 4454 & 0.499 & 0.500 & 0 & 1 \\
RiskRating & 4454 & 22.918 & 40.834 & 0.5 & 00 \\
Income & 4454 & 700.814 & 521.454 & 0 & 1400 \\
TypeofInvestment & 4454 & 0.003 & 0.060 & 0 & 1 \\
Residence & 4454 & 0.324 & 0.468 & 0 & 1 \\
Default & 4454 & 0.231 & 0.422 & 0 & 1 \\
\hline
\end{tabular}

Note. Source: Research data.

Table 3 presents the results of the proposed model. From its analysis, it can be seen that the variables gender (variable of interest), risk classification, income, type of investment, residence and default were significant. However, the variables age and civil status were not significant. It is worth noting that even though they are not significant, the variables age and civil status were maintained to avoid endogeneity and bias of omitted variables (ratified by the Durbin Wu Hausman test), considering their theoretical important for the model. In addition, the constant was also significant at a significance value of $1 \%$. 
Table 3

Results of the Proposed Model

\begin{tabular}{cc}
\hline \multicolumn{2}{c}{ Dependent Variable: $\log ($ ContractedAmount $)$} \\
\hline Independent Variables \\
Constant & $8.2847^{* *}$ \\
Gender & $(0.0177)$ \\
& $0.0191^{*}$ \\
Age & $(0.0082)$ \\
& -0.0001 \\
CivilStatus & $(0.0003)$ \\
& -0.0095 \\
RiskRating & $(0.0086)$ \\
& $-0.0001^{* *}$ \\
Income & $(0.0003)$ \\
& $0.00007^{* *}$ \\
TypeofInvestment & $(8.53 \mathrm{e}-06)$ \\
& $1.0329^{* *}$ \\
Residence & $(0.1393)$ \\
& $-0.3133^{* *}$ \\
Default & $(0.0124)$ \\
& $-0.3173^{* *}$ \\
$\mathrm{~N}^{\circ}$ Observations & $(0.235)$ \\
\hline R ${ }^{2}$ & 4454 \\
\hline
\end{tabular}

Note. Source: Research data.

* Indicates significant at 5\%; ** Indicates significant at $1 \%$.

Based on the above considerations, it is possible to analyze the effect of each significant variable specifically. Thus, analyzing the control variables, we can see that these presented the expected signs, which are: the income variable has a positive effect, despite a small magnitude; the type of fixed investment showed a positive relation with the contracted amount, taking into account that it brings more security to the bank that grants the credit; risk classification presented a negative relation in which the higher the percentage of risk, the higher the risk and the lower the contracted amount; the residence variable has a negative effect for residents in rural areas; and default presented a negative relation of great magnitude, as expected, since defaulting clients represent a greater risk of payment regarding the contracted amount, which consequently reduces it.

On the variable of interest, gender, we can observe that women obtain a value approximately $1.91 \%$ higher than men. In addition, we can see that the proposed model presented a $\mathrm{R}^{2}$ of 0.4231 , which according to Hair, Anderson, Tatham and Black (2005), represents the variance percentage of the dependent variable explained by the set of independent variables. Therefore, we estimated that approximately $42.31 \%$ of variable lContracted Amount is explained by a set of dependent variables.

It is worth saying that there is normality, due to the large sample that was used, and that the presented results were obtained with the use of robust errors, since the initially estimated model has heteroscedasticity, according to the Breusch-Pagan test. This does not point to the presence of bias of inconsistency in the OLS estimators, but invalidates the standard errors and usual test statistics. This 
way, standard errors and robust $t$ statistics were calculated regarding heteroscedasticity, which is routinely done by many econometric programs (Wooldridge, 2012).

In addition, VIF and Tolerance tests were also performed to test the multicollinearity assumption, and the Durbin-Watson test to test the assumption of serial autocorrelation. As a result, it was discovered that there was absence in both tests, which means that the assumptions were not violated.

Finally, the analysis was also made regarding interactions of gender and all other variables to check if the effect is not related to other conditions. The analysis was made from the original model with addition of one interaction at a time to avoid overlap problem or multicollinearity. As a result, the interaction variable genderXincome was the only one found with significance, as presented in Table 4 .

Table 4

Results of the Proposed Model with the Interaction Variable GenderXIncome

\begin{tabular}{|c|c|}
\hline \multicolumn{2}{|c|}{ Dependent Variable: $\log ($ ContractedAmount $)$} \\
\hline \multicolumn{2}{|c|}{ Independent Variables } \\
\hline Constant & $\begin{array}{l}8.2707 * * \\
(0.0187)\end{array}$ \\
\hline Gender & $\begin{array}{l}0.0473 * * \\
(0.0165)\end{array}$ \\
\hline Age & $\begin{array}{l}-0.0001 \\
(0.0003)\end{array}$ \\
\hline CivilStatus & $\begin{array}{l}-0.0092 \\
(0.0086)\end{array}$ \\
\hline RiskRating & $\begin{array}{r}0.0001 \\
(0.0002)\end{array}$ \\
\hline Income & $\begin{array}{l}0.00009 * * \\
(0.00001)\end{array}$ \\
\hline TypeofInvestment & $\begin{array}{l}1.0334 * * \\
(0.1390)\end{array}$ \\
\hline Residence & $\begin{array}{c}-0.3132 * * \\
(0.0124)\end{array}$ \\
\hline Default & $\begin{array}{c}-0.3169 * * \\
(0.235)\end{array}$ \\
\hline GenderXIncome & $\begin{array}{l}-0.00004 * \\
(0.00002)\end{array}$ \\
\hline $\mathrm{N}^{\mathrm{o}}$ Observations & 4454 \\
\hline $\mathrm{R}^{2}$ & 0.4239 \\
\hline
\end{tabular}

Note. Source: Research data.

* Indicates significant at 5\%;** Indicates significant at $1 \%$.

Since the control variables continue to display the same signals as the original model, it is possible to analyze only the effect of the added interaction variable. In the first place, it can be seen that the gender variable presents a greater magnitude than in the original model (4.7\%), that is, we can observe that women obtain a value approximately $4.7 \%$ higher than men. 
However, as the signal from genderXincome was negative, as the income for women increases, the effect on the I(ContractedAmount) dependent variable decreases. This explains why the gender variable presented the value of $1.91 \%$ in the original model, because measuring the partial effect of gender $\left(\frac{\Delta y}{\Delta x_{1}}=\beta_{1}+\beta_{9} x_{4}\right)$ with the average value of the income (700.814) of the sample, we have the same result $[0.047-0.00004(700.814) \cong 0,019]$.

Therefore, we noticed that the income has a direct impact on the gender in relation to the amounts that were granted in microcredit operations. In addition, we can see that approximately $42.39 \%$ of $\mathbf{l}($ ContractedAmount) variable is explained by this model.

\section{Discussion}

The studies described above, especially in relation to gender, the variable of interest, are different from those found in literature, although this type of relationship has not been yet explored. Thus, in opposition to the study by Agier and Szafarz (2013), which points out that women get a disproportional credit size when compared to men, and in opposition to the research by D'Espallier et al. (2011), Malapit (2012) and Ugwuja and Nweze (2018), which identified that female clients are associated with lower loans, the results of the present work suggest otherwise. The results show that women get a value that is approximately $1.91 \%$ higher than men.

An important finding worthy of consideration is the effect of income on gender, obtained by the analysis of the genderXincome interaction variable. It was perceived that as the income for women increases, the effect on the $\mathbf{l}$ (ContractedAmount) dependent variable decreases. This factor can be explained by the focus of microcredit programs on low-income people to combat poverty, as posed by several authors, such as: Bezboruah and Pillai (2017), Thanh and Duong (2017), Bidisha, Khan, Imran, Khondker and Suhrawardy (2017), Arbolino, Carlucci, Cirà, Yigitcanlar and Ioppolo (2018), Dutta and Banerjee (2018) and Ugwuja and Nweze (2018).

It is also necessary to consider the factors that deal with the issue of gender discrimination, still very much debated in the literature, with still controversial evidence. This is debated for the Brazilian scenario in a study recently published by Proni and Proni (2018).

Regarding the fight against discrimination in work in the Brazilian scenario, for example, Proni and Proni (2018) bring some important inferences in their recent study. The authors point out that the fight against gender discrimination brought about by the evolution of labor legislation has not been able to eliminate the differences in terms of career advancement and remuneration between men and women, particularly in large companies. However, the study also shows that there are initiatives for promoting gender equity in the corporate world, but that progress is still slow. This helps to explain why, unlike the results of the studies similar to the one proposed here, women ended up with a contracted value only slightly higher than men, despite the large focus on women in microcredit programs.

This clear preference for microcredit programs by women is addressed by the studies of Gonzalez, Righetti and Di Serio (2014), Silva, Fonseca and Santos (2016) and Mendonça and Soares (2016), focused on the Brazilian context. The study by Gonzalez et al. (2014) evaluated the impact of productive microcredit provided by a microfinance institution linked to a commercial bank. In their study, $64 \%$ of the total number of clients are women and the reason for this is, according to microcredit agents, that men seek more security in a formal job while women look for jobs that can reconcile with housework.

Silva, Fonseca and Santos (2016) verified the influence of microcredit in the development of microbusinesses and in the quality of life of the microentrepreneurs' families in Brazil. The results show the Program preference in benefitting women and encouraging their economic activity. 
Mendonça and Soares (2016) pointed out that women are important for the sustainability of the microcredit program. In their study, the authors discussed client performance of a microcredit program through the estimation of growth trajectories of the operating profit of their microenterprises. The results revealed that men have a somewhat higher return than women in relation to profit development. However, women have more stable trajectories, that is, they prefer conservative evolutions in the business, which is important for the sustainability of the microcredit program itself. In this respect, the program's tendency to give preference to solidarity groups with a larger number of women is justified.

Finally, we cannot ignore other factors already discussed during the study that favor women in microcredit programs, such as default, because women borrowers are trustworthy in loan repayment compared to men (Al-Shami et al., 2017; Bahta et al., 2017; Bilau \& St-Pierre, 2018), the fact that women are less likely to misuse the loan (Ghosh \& Neogi, 2017) and to contribute to the economy (Bezboruah \& Pillai, 2017) and to household welfare (Al-Shami et al., 2017).

Despite this new finding, the results obtained in this study are just an initial kick-off on this topic. In this sense, based on the findings that were presented here, other works may be developed to foster this area, for example, by exploring whether the observed fact occurred due to regional social characteristics of the sample, or even which destination this women have given to the values obtained, investigating whether the microcredit granting has contributed to women's empowerment or their exit of poverty condition through employment and income generation, as studies have shown (Alves \& Camargos, 2014; Chliova et al., 2015; Leismann \& Carmona, 2010).

In addition, it is also important to analyze whether the factors presented in literature, such as the ones pointed out by Nader (2008) on cost-efficiency, equity ratio and women's multiplier effect, were determinant for the sample and for other possibly tested samples. It is also worth noting that, although women received $1.91 \%$ higher amounts in the analyzed sample, another question to be discussed is the satisfaction of these women regarding the amounts, since according to Ganle et al. (2015), 92\% of rural women from Ghana that were served by a microcredit program believed that the granted amount was insufficient.

\section{Conclusion}

The aim of this research was to evaluate the relationship between gender and the amounts which were granted in microcredit operations. By using a multiple linear regression technique on a sample constituted by 4,454 microcredit clients of branches of a bank located in Paraíba, the proposed model made it possible to analyze the relationship of the gender with the grants amounted by microcredit operations.

We inferred that women obtain values approximately $1.91 \%$ higher than men, which is the opposite of other studies found in literature, in which women obtain a disproportional value credit when compared to men. It should be noted that all variables were significant and that the proposed model showed that approximately $42.31 \%$ of the variable lContracted Amount is explained through the set of independent variables that were used. In addition, we perceived that as the income for women increases, the effect on the $\mathbf{l}$ (ContractedAmount) dependent variable decreases.

As a practical implication of this study, we hope that the obtained results will contribute to a better understanding of the credit granting process, especially regarding gender. We also emphasize that the research fulfilled its purposes, obtaining relevant results that can be used to support future research, which may be methodologically similar to the present study, but with a most representative sample or from another locale. Besides this, it is worth mentioning that this field is very fertile for further analysis of the results, as already mentioned in the discussion session of this study. 
Finally, it is important to mention this study's limitations. First, it should be noted the specificity of the sample that was investigated, so that in spite of bringing new findings, a broader analysis of other realities is necessary for the analysis of possible different results.

Secondly, it is also important to highlight the limitation in relation to the size of effect. As inferred in this study, the results pointed to an effect of only $1.91 \%$ in relation to gender, which is a small result. In addition, as Nelson (2015) demonstrated in his study on risk averseness between women and men, it is necessary to have more attention to the quantitative sizes of differences and similarities with the regression coefficients. Nelson stated that regression coefficients are not meaningful estimates of effect sizes if a researcher searches for and reports on only those combinations of variables or subsamples that yield statistically significant results, or the results that the researcher finds most plausible, and thus suggests the use of tools such as Cohen's d and the Index of Similarity.

\section{Contributions}

Conception and design of study: 1st author and 2nd author

Writing and analysis of the manuscript: 1st author and 2nd author

Discussion of results: 2nd author and 1st author

Final revision: 2nd author and 1st author

\section{References}

Abendroth, A.-K., Melzer, S., Kalev, A., \& Tomaskovic-Devey, D. (2017). Women at work: Women's access to power and the gender earnings gap. ILR Review, 70(1), 190-222. https://doi.org/10.1177/0019793916668530

Agier, I., \& Szafarz, A. (2013). Microfinance and gender: Is there a glass ceiling on loan size?. World Development, 42, 165-181. https://doi.org/10.1016/j.worlddev.2012.06.016

Akotey, J. O., \& Adjasi, C. K. D. (2016). Does microcredit increase household welfare in the absence of microinsurance? $\quad$ World Development, 37, 380-394. https://doi.org/10.1016/j.worlddev.2015.09.005

Al-Shami, S. S. A., Majid, I., Mohamad, M. R., \& Rashid, N. (2017). Household welfare and women empowerment through microcredit financing: Evidence from Malaysia microcredit. Journal of Human Behavior in the Social Environment, 27(8), 894-910. https://doi.org/10.1080/10911359.2017.1345341

Alves, C. M., \& Camargos, M. A. (2014). Fatores condicionantes da inadimplência em operações de microcrédito. Revista de Administração e Contabilidade das UNISINOS, 11(1), 59-74. https://doi.org/10.4013/base.2014.111.05

Arbolino, R., Carlucci, F., Cirà, A., Yigitcanlar, T., \& Ioppolo, G. (2018). Mitigating regional disparities through microfinancing: An analysis of microcredit as a sustainability tool for territorial development in Italy. Land Use Policy, 70, 281-288. https://doi.org/10.1016/j.landusepol.2017.10.042

Armstrong, K., Ahsan, M., \& Sundaramurthy, C. (2018). Microfinance ecosystem: How connectors, interactors, and institutionalizers co-create value. Business Horizons, 61(1), 147-155. https://doi.org/10.1016/j.bushor.2017.09.014 
Aterido, R., Beck, T., \& Iacovone, I. (2013). Access to finance in sub-saharan Africa: Is there a gender gap?. World Development, 47, 102-120. https://doi.org/10.1016/j.worlddev.2013.02.013

Bahta, Y. T., Strydom, D. B., \& Donkor, E. (2017). Microcredit and gender empowerment: Policy implications for sustainable agricultural development in Eritrea. Development in Practice, 27(1), 90-102. https://doi.org/10.1080/09614524.2017.1259393

Bezboruah, K., \& Pillai, V. (2017). Microcredit and development: a multi-level examination of women's participation in microfinance institutions. Development in Practice, 27(3), 328-339. https://doi.org/10.1080/09614524.2017.1298723

Bidisha, S. H., Khan, A., Imran, K., Khondker, B. H., \& Suhrawardy, G. M. (2017). Role of credit in food security and dietary diversity in Bangladesh. Economic Analysis and Policy, 53, 33-45. https://doi.org/10.1016/j.eap.2016.10.004

Bilau, J., \& St-Pierre, J. (2018). Microcredit repayment in a European context: Evidence from Portugal. The Quarterly Review of Economics and Finance, 68, 85-96. https://doi.org/10.1016/j.qref.2017.11.002

Brana, S. (2013). Microcredit: An answer to the gender problem in funding?. Small Business Economics, 40(1), 87-100. https://doi.org/10.1007/s11187-011-9346-3

Camargos, M. A., Camargos, M. C. S., \& Araujo, E. A. (2012). A inadimplência em um programa de crédito de uma instituição financeira pública de Minas Gerais: Uma análise utilizando regressão logística. Revista de Gestão, 19(3), 467-486. https://doi.org/10.5700/rege475

Camargos, M. A., Camargos, M. C. S., Santos, F. S., Rodrigues, P. J., \& Silva, F. W. (2010). Fatores condicionantes da inadimplência em processos de concessão de crédito a micro e pequenas empresas do estado de Minas Gerais. Revista de Administração Contemporânea, 14(2), 333-352. Retrieved from http://www.scielo.br/pdf/rac/v14n2/v14n2a09.pdf. https://doi.org/10.1590/s1415-65552010000200009

Carlucci, F., Cirà, A., Immordino, G., Ioppolo, G., \& Yigitcanlar, T. (2017). Regional heterogeneity in Italy: Transport, devolution and corruption. Land Use Policy, 66, 28-33. https://doi.org/10.1016/j.landusepol.2017.04.020

Chliova, M., Brinckmann, J., \& Rosenbusch, N. (2015). Is microcredit a blessing for the poor? A metaanalysis examining development outcomes and contextual considerations. Journal of Business Venturing, 30(3), 467-487. https://doi.org/10.1016/j.jbusvent.2014.10.003

Corsi, M., \& Angelis, M. D. (2017). Gender discrimination in microfinance? Some evidence from Uganda. The Journal of Development Studies, 53(5), 723-740. https://doi.org/10.1080/00220388.2016.1205733

Das, K. (2017). Going through the new avenue of life: A study on factors working behind entrepreneurship development through self-help group. In C. Neogi, A. K. Bhandari, \& S. Ghosh (Eds.), Women's entrepreneurship and microfinance (Vol. 1, Chap. 9, pp. 157-171). Singapore: Springer.

D’Espallier, B., Guérin, I., \& Mersland, R. (2011). Women and repayment in microfinance: A global analysis. World Development, 39(5), 758-772. https://doi.org/10.1016/j.worlddev.2010.10.008

Dutta, A., \& Banerjee, S. (2018). Does microfinance impede sustainable entrepreneurial initiatives among women borrowers? Evidence from rural Bangladesh. Journal of Rural Studies, 60, 70-81. https://doi.org/10.1016/j.jrurstud.2018.03.007 
Enimu, S., Eyo, E. O., \& Ajah, E. A. (2017). Determinants of loan repayment among agricultural microcredit finance group members in Delta state, Nigeria. Financial Innovation, 3(21), 1-12. https://doi.org/10.1186/s40854-017-0072-y

Ganle, J. K., Afriyie, K., \& Segbefia, A. Y. (2015). Microcredit: Empowerment and disempowerment of rural women in Ghana. World Development, 66, 335-345. https://doi.org/10.1016/j.worlddev.2014.08.027

García-Pérez, I., Muñoz-Torres, M.-J., \& Fernández-Izquierdo, M.-Á. (2017). Microfinance literature: A sustainability level perspective survey. Journal of Cleaner Production, 142(4), 3382-3395. https://doi.org/10.1016/j.jclepro.2016.10.128

Garikipati, S., Johnson, S., Guérin, I., \& Szafarz, A. (2017). Microfinance and gender: Issues, challenges and the road ahead. The Journal of Development Studies, 53(5), 641-648. https://doi.org/10.1080/00220388.2016.1205736

Ghosh, S., \& Neogi, C. (2017). Access to finance, entrepreneurship, and empowerment: A case study. In C. Neogi, A. K. Bhandari, \& S. Ghosh (Eds.), Women's entrepreneurship and microfinance (Vol. 1, Chap. 10, pp. 173-189). Singapore: Springer. https://doi.org/10.1007/978-981-10-4268$3 \_10$

Ghosh, S., \& Vinod, D. (2017). What constrains financial inclusion for women? Evidence from Indian micro data. World Development, 92, 60-81. https://doi.org/10.1016/j.worlddev.2016.11.011

Gonzalez, L., Righetti, C., \& Di Serio, L. C. (2014). Microcrédito e impacto sobre a geração de renda: $\mathrm{O}$ caso do Banco Real. Revista de Economia Contemporânea, 18(3), 453-476. http://dx.doi.org/10.1590/141598481837

Guérin, I., D'Espallier, B., \& Venkatasubramanian, G. (2015). The social regulation of markets: Why microcredit fails to promote jobs in rural South India. Development and Change, 46(6), 12771301. https://doi.org/10.1111/dech.12197

Haile, H. B., Bock, B., \& Folmer, H. (2012). Microfinance and female empowerment: Do institutions matter?. Women's Studies International Forum, 35(4), 256-265. https://doi.org/10.1016/j.wsif.2012.04.001

Hair, J. F., Jr., Anderson, R. E., Tatham, R. L., \& Black, W.C. (2005). Análise multivariada de dados. (5a ed.). Porto Alegre: Bookman.

Leismann, E. L., \& Carmona, C. U. M. (2010). Sustentabilidade financeira das instituições de microfinanças brasileiras: Análise das cooperativas de crédito singulares. Revista de Economia e Sociologia Rural, 48(4), 635-672. https://doi.org/10.1590/s0103-20032010000400007

Li, X., Gan, C., \& Hu, B. (2011). Accessibility to microcredit by Chinese rural households. Journal of Asian Economics, 22(3), 235-246. https://doi.org/10.1016/j.asieco.2011.01.004

Mahmud, S., Shah, N. M., \& Becker, S. (2012). Measurement of women's empowerment in rural Bangladesh. World Development, 40(3), 610-619. https://doi.org/10.1016/j.worlddev.2011.08.003

Malapit, H. J. L. (2012). Are women more likely to be credit constrained? Evidence from low-income urban households in the Philippines. Feminist Economics, 18(3), 81-108. https://doi.org/10.1080/13545701.2012.716161

Mazumder, R., Dastidar, S., \& Bhandari, A. K. (2017). Access to credit and microentrepreneurship: A gender comparison. In C. Neogi, A. K. Bhandari, \& S. Ghosh (Eds.), Women's entrepreneurship and microfinance (Vol. 1, Chap. 11, pp. 191-210). Singapore: Springer. 
Mendonça, K. V., \& Soares, R. B. (2016). Trajetória de crescimento para microempreendedores: Diferencial de gênero dos clientes do programa crediamigo. Estudos Econômicos, 46(3), 701731. https://doi.org/10.1590/0101-416146373kvr

Milanov, H., Justo, R., \& Bradley, S. W. (2015). Making the most of group relationships: The role of gender and boundary effects in microcredit groups. Journal of Business Venturing, 30(6), 822838. https://doi.org/10.1016/j.jbusvent.2015.04.001

Ministério do Trabalho e Previdência Social. (2015, dezembro 3). Informações gerenciais do Programa Nacional de Microcrédito Produtivo Orientado $-3^{\circ}$ Trimestre de 2015. Brasília, DF: Autor. Retrieved from http://portalfat.mte.gov.br/wp-content/uploads/2016/03/RELATORIO-PNMPO$3 \% \mathrm{C} 2 \%$ BA-TRI-2015.pdf

Nader, Y. F. (2008). Microcredit and the socio-economic wellbeing of women and their families in $\begin{array}{llll}\text { Cairo. The Journal of } & \text { Socio-Economics, 37(2), 644-656. }\end{array}$ https://doi.org/10.1016/j.socec.2007.10.008

Nelson, J. A. (2015). Are women really more risk-averse than men? A re-analysis of the literature using expanded methods. Journal of Economic Surveys, 29(3), 566-585. https://doi.org/10.1111/joes.12069

Proni, T. T. R. W., \& Proni, M. W. (2018). Discriminação de gênero em grandes empresas no Brasil. Revista Estudos Feministas, 26(1), 1-23. https://doi.org/10.1590/1806-9584.2018v26n141780

Rakib, M., Chakrabarty, S., \& Winn, S. (2018). Gender-differentiated social and human capital and the use of microcredit in Bangladeshi female entrepreneurship. In É. Ní Shé, L. J. Burton, \& P. Danaher (Eds.), Social capital and enterprise in the modern state (Vol. 1, Chap. 9, pp. 181-202). Cham: Palgrave Macmillan.

Resolução n. 2.682, de 21 de dezembro de 1999. (1999). Dispõe sob critérios de classificação das operações de crédito e regras para constituição de provisão para créditos de liquidação duvidosa. Retrieved from http://www.bcb.gov.br/pre/normativos/res/1999/pdf/res_2682_v2_L.pdf

Santos, C. G., \& Carrion, R. S. M. (2009). Microcrédito e pobreza: Um diálogo possível? [Edição Especial]. Revista de Administração Contemporânea, 13, 53-67. Retrieved from http://www.scielo.br/pdf/rac/v13nspe/a05v13nspe.pdf. 65552009000500005

Serrano-Cinca, C., Gutiérrez-Nieto, B., \& Reyes, N. M. (2016). A social and environmental approach to microfinance credit scoring. Journal of Cleaner Production, 112, 3504-3513. https://doi.org/10.1016/j.jclepro.2015.09.103

Silva, W. A. C., Fonseca, R. F., \& Santos, A. O. (2016). Desenvolvimento dos micronegócios e a qualidade de vida das famílias dos microempreendores. Revista de Administração Mackenzie, 17(4), 176-200. http://dx.doi.org/10.1590/1678-69712016/administracao.v17n4p176-200

Soares, R. B., Barreto, F. A., \& Azevedo, M. T. (2011). Condicionantes da saída da pobreza com microcrédito: O caso dos clientes do Crediamigo. Estudos Econômicos, 41(1), 119-142. https://doi.org/10.1590/s0101-41612011000100005

Steil, A. V. (1997). Organizações, gênero e posição hierárquica - compreendendo o fenômeno do teto de vidro. Revista de Administração, 32(3), 62-69. Retrieved from http://200.232.30.99/busca/artigo.asp?num_artigo=200

Tahir, M. W., Kauser, R., Bury, M., \& Bhatti, J. S. (2018, May). 'Individually-led' or 'female-male partnership' models for entrepreneurship with the BISP support: The story of women's financial and social empowerment from Pakistan. Women's Studies International Forum, 68, 1-10. https://doi.org/10.1016/j.wsif.2018.01.011 
Thanh, P. T., \& Duong, P. B. (2017). Health shocks and the mitigating role of microcredit - The case of rural households in Vietnam. Economic Analysis and Policy, 56, 135-147. https://doi.org/10.1016/j.eap.2017.08.006

Ugwuja, V. C., \& Nweze, N. J. (2018). Gender analysis of micro-loan sizes accessed by small-scale agro-entrepreneurs in the Niger Delta region of Nigeria. Journal of Development and Agricultural Economics, 10(1), 15-21. https://doi.org/10.5897/jdae2017.0878

Vyas, S., Jansen, H. A. F. M., Heise, L., \& Mbwambo, J. (2015). Exploring the association between women's access to economic resources and intimate partner violence in Dar es Salaam and Mbeya, Tanzania. Social Science \& Medicine, 146, 307-315. https://doi.org/10.1016/j.socscimed.2015.10.016

Wahidi, I. (2017). Microcredit in Lebanon: First data on its beneficiaries. International Business Research, 10(4), 32-41. https://doi.org/10.5539/ibr.v10n4p32

Wooldridge, J. M. (2012). Introdução à econometria: Uma abordagem moderna (4a ed.). São Paulo: Cengage Learning.

Zhang, Q., \& Posso, A. (2017). Microfinance and gender inequality: Cross-country evidence. Applied Economics Letters, 24(20), 1494-1498. https://doi.org/10.1080/13504851.2017.1287851

Zouain, D. M., \& Barone, F. M. (2007). Excertos sobre política pública de acesso ao crédito como ferramenta de combate à pobreza e inclusão social: O microcrédito na era FHC. Revista de Administração Pública, 41(2), 369-380. https://doi.org/10.1590/s0034-76122007000200010

\section{Authors' Profiles}

Camila Cristina Rodrigues Salgado

Universidade Federal da Paraiba - DCSA, Cidade Universitária, 58220-000, Bananeiras, PB, Brazil. E-mail address: adm.camilarodrigues@hotmail.com. https://orcid.org/0000-0002-2018-8763

Renan Felinto de Farias Aires

Universidade Federal Rural do Semi-Arido, Rua Francisco Mota, 572, 59625-900, Presidente Costa e Silva, Mossoro, RN, Brazil. E-mail address: renan.aires@ufersa.edu.br. https://orcid.org/0000-0001-9326-5371 